\title{
Model of Supervision Based on Primary School Teacher Professional Competency in Tematic Learning in Curriculum 2013
}

\author{
Meilani Hartono* \\ ${ }^{1}$ Elementary Teacher Education Department, Faculty of Humanities, Bina Nusantara University, Jakarta, Indonesia
}

\begin{abstract}
This study aims to find the Supervision Model Based on Primary Teacher Professional Competence which effective on integrated learning. This study use research and development with qualitative approach which will be carried out in the Palmerah, West Jakarta. The techniques used to collect data are interviews, questionnaires, observation and documentation. Data $\mathrm{v}$ alidity is tested with credibility, transferability, dependability, and comfortability. The model developed will be validated using the Delphi technique. The result of this research is the discovery of the model and devicebased supervision model of professional competence of primary teachers in integrated learning. The long-term goal of this research is to improve the teachers' competence and the supervision quality for primary teachers in integrated learning
\end{abstract}

\author{
Keywords: \\ Supervision; \\ Primary Teacher \\ Professional Competence; \\ Integrated Learning;: \\ 2013 th Curriculum
}

\section{Introduction}

One of the main factors to determine the quality of education is the teacher. Efforts to improve the education quality should start from the teacher. In fact, the results of teacher competence test in 2015 have not met expectations. Further reason is a curriculum change where elementary schools are required to implement thematic learning. This means that an elementary school teacher should have a complete mastery of material on all subjects in elementary school. In fact, not all elementary school teachers have a Primary School Teacher Education background.

Usman (2009) stated that teachers are closely related to the quality of school graduates and he also suggested that the quality of teachers are considered as the defining factor of school output quality. Hill (2005) states the competence of teachers is very influential on the achievement of first and last class student learning outcomes. In fact, the result of the competency test of teachers has not been satisfying and the results of national examinations with high scores are not precise to be used as a benchmark for teachers because there may be other factors that influence them.

One effort to improve the quality of teachers is to carry out supervision, Supervision of a supervisory action that must be implemented in schools to be used by teachers to improve themselves and refine the plan if the teachers find errors in the field. On the other hand, the supervision function becomes a standard for teachers to measure their performance and to improve their competence.

Supervision is important as one way to improve and improve the quality of learning. Teachers need supervision to improve their teaching skills. Improvement of teachers teaching ability have significant effect on student achievement. Supervisors are seen close to the teacher, but unfortunately the teacher has his own thoughts on the supervisor, even on the other hand the results of supervision is also in doubt. Supervisor and teacher seemed to be in two opposite poles. The teacher views the supervisor as a person who creates fear and stress, is interrogated and like creating punishment for the teacher. On the opposite, the supervisor thinks that interrogating teachers will never come to an end.

Dodeen (2012) stated: "teachers should be prepared to teach all the topics, they should continuously participate in professional development programs". Teachers should be ready to teach all topics and teachers should create a sustainable professional development program. Teachers must participate in the continuing professional program. The continuous professional development program aims to solve problems in learning. Teachers cannot create the program itself, the teachers need the help of someone else who is

\footnotetext{
* Corresponding author.

E-mail Addresses: mhartono@binus.edu (Meilani Hartono)
} 
considered to have more competence than himself. Other people who are considered to have more competence than teachers are principals and supervisors who act as supervisors. Various studies conclude that supervisors have close relationships with teachers, but teachers think that supervisors have a prejudice that teachers are incompetent about the subjects being taught. Supervisors are seen to perform inspection skills, be judgmental and have dominance from the point of view of ivory towers. Teachers also have doubts about the supervisor's supervisory results. This means teachers and supervisors are on two opposing camps.

Supervision is an activity which must be implemented in the of education process. In the implementation of supervision in Indonesia, inspectors, observers and heads of education units (principals) serve as supervisors. In fact, the implementation of supervision is not in accordance with expectations because the requirements of competence, recruitment and selection patterns, as well as evaluation and promotion of supervisory positions do not reflect the great attention to the importance of implementation of supervision on the root of education is the interaction of teaching and learning in the classroom.

In the 2013 Curriculum, thematic learning is used in elementary school. Thematic learning is learning that is packaged in the form of themes based on the content of several subjects that are combined or integrated. The theme is a container or vehicle to introduce various material concepts to the students thoroughly. Thematic is provided with the intention of uniting curriculum content in units or intact units to make the pursuit of the learning meaningful, full of values and easily understood by the students.

Thematic learning is one of the approaches in integrated learning (integrated instruction) which is a learning system that allows students, both individually and in groups, actively explore and discover the concept and principles of science holistically, meaningful and authentic.

Integrated learning is oriented to the learning practices that meet the needs and development of students. This approach departs from the theory of learning to reject the practice or memorization process (drill) as the basis for the formation of children's intellectual knowledge and structure.

Thematic learning model is a learning model that uses a thematic approach that involves some content of the subject to provide meaningful experiences to the students. The focus of attention in thematic learning lies in the process that students take when trying to understand the content of learning in line with the forms of skills that must be developed.

In practice, this thematic approach is based on a theme chosen and developed by teachers with students with due regard to their relevance to the subject content. The theme is the main idea or idea that is the subject of the conversation (Poerwadarminta, 1983). The purpose of this theme is not only to master the concepts in a subject, but also to the concepts of other lessons.

The implementation of thematic learning in elementary school makes the implementation of supervision increasingly ineffective. Supervisors do not have sufficient time to supervise along one lesson because of tasks and occupations.

Based on these thoughts and facts, a model of appropriate supervision development in elementary school in thematic learning is needed. A more sophisticated expectation is in parallel to improve the quality of education in Indonesia.

\section{Method}

This research is designed with research and development approach. Based on the concept of research and development developed by Gall, Gall and Borg (2003). Sugiyono (2008: 298), Sukmadinata in Musadad (2013: 132). Research and development developed in this research consists of three stages: preliminary study stage, development stage and validation stage.

The focus of the exploratory study in this study is the Competency-Based Professional Teacher Elementary Supervision Model on Thematic Learning in the Curriculum 2013 with a qualitative approach. According to Lofland and Lofland in Moleong (2012: 157) The source of data in qualitative research is the words and the rest of the action is additional data in the form of documents and others. In this study, the data types are divided into: (1) words, (2) written data sources, (3) photos, and (4) data (4) statistics.

The research was conducted in Palmerah Subdistrict by taking samples of Head of District III. Data collection using interview technique, questionnaire and document study. Data analysis techniques are conducted simultaneously with data collection. The data analysis technique used is qualitative description. Miles and Hubermana in Sugiyono (2011: 334) stated that the qualitative data analysis is done interactively by data reduction process, display data and conclusion drawing / verification.

The data validity test consists of credibility test (internal validity), dependability test (data reliability), transferability test (external validity / generalization) and comfirmability test (objectivity). The credibility test is conducted with extension of observation, increased persistence in research, triangulation and discussion with peers and member check (Sugiyono, 2011) 


\section{Results and Discussion}

Based on the data obtained in the field, can be made empirical model of supervision of elementary school teachers. Furthermore, the model design was developed from the exploration of empirical models in the field and literature review. Based on the findings and Focus Group Discussion that has been done, the improvement of Professional Competence Based Design Supervision Model. The FGD was attended by Supervisors and Principals. The result of the FGD is a hypothetical model. The final model is obtained by conducting expert test using Delphi technique. In this study, Delphi techniques are used with the aim of the experts making decisions about the feasibility and applicability of the model.

The model has a supervision program planning component consisting of needs analysis, programming and program design. Program planning is made with teacher initiative. Supervisors consist of supervisors or principals, may request input from senior teachers and learners to improve the objectivity of supervision. Senior teachers in this model of supervision are elementary school teachers with the following criteria: 1) being an active primary school teacher in a school where the teacher is teaching or an elementary school teacher from another school active in KKG activities; 2) have teaching experience or working period of 5 to 10 years or 10,000 hours; 3) have commitment and motivation to assist the improvement of the competence of elementary school teachers; And 4) able to provide an objective assessment and input.

Instruments used in Competency-Based Supervision Models of Teacher Professionals in Thematic lessons are: 1) Classroom observation instruments as supervisor's guidance perform class observations to determine needs analysis; 2) Instrument of professional competency test to map the mastery of teacher material. Instrument of professional competence test containing questions to map teacher weakness. The questions in this professional competency test are not like the ones on the national exam. The questions in this instrument are questions that require a review of the minimum mastery indicator for elementary school teachers; 3) Academic Supervision Instrument RPP Field to assess teacher ability in developing syllabus; 4) Supervision Instrument Learning Activities to assess the ability of teachers to plan lesson implementation; 5) Instrument Supervision of Administrative Assessment Learning to assess the ability of teachers to implement learning; 6) Academic Supervision Instrument of Classroom Teacher Administration; 7) Academic Supervision Instrument in the Evaluation of Learning Results; 8) Academic Supervision Instrument of Classroom Management; and 9) Academic Supervision Instrument for Counseling Guidance

Procedures for the implementation of supervisory models based on the competence of teachers of elementary schools on thematic learning are: 1) Teachers fill out the planning and supervision planning sheet; 2) The teacher asks the supervisor to be supervised; 3) Teachers and supervisors have initial meetings to determine needs analysis and planning; 4) The teacher performs a professional competency test whose results are discussed with the senior teacher, the result is written a planning sheet and supervision exercise; 5) Senior teachers conduct class observations using classroom observation guidelines, the results are written a planning sheet and supervision implementation; 6) Supervisor accompanied by a senior teacher supervises class visits and assesses teachers using instruments number 3 through number 9; 7) Supervisors and teachers hold discussions discussing the things found in supervision; And 9) The teacher writes the results in the planning sheet and supervision implementation. In summary, the flow of Supervision Model based on Professional Teacher Competency of SD on Thematic Learning in Curriculum 2013 can be seen in Figure 1. 


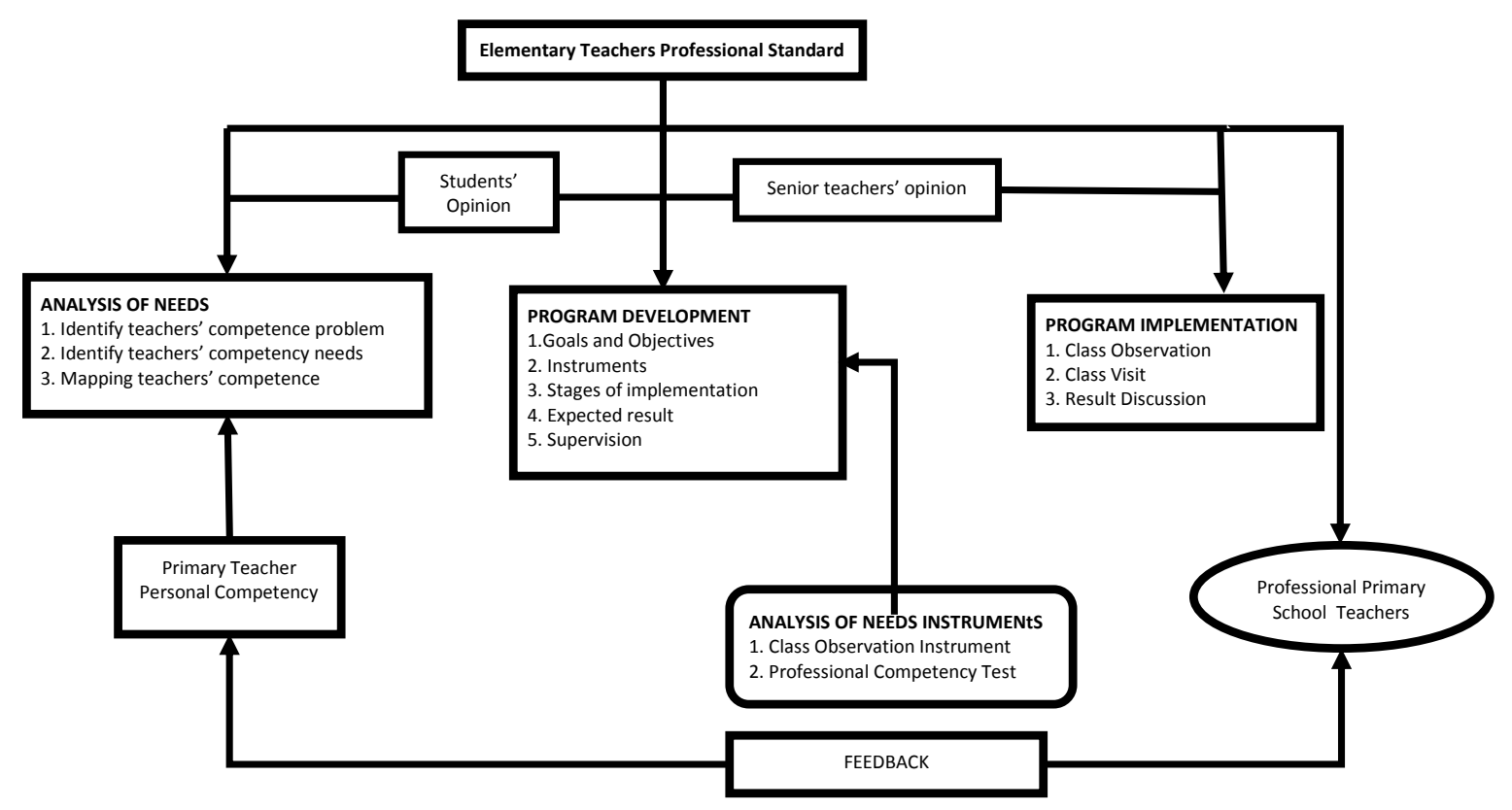

Figure 1. The Flow of Supervision Model based on Professional Teacher Competency of SD on Thematic Learning in Curriculum 2013

The execution time of the stages in this model are: 1) Class observation and supervision of class visits conducted during teacher hours teaching, the class that is observed is the class that will be used during class visit; and 2) Other activities are conducted outside the teaching hours of teachers so as not to interfere with teachers and teaching and learning activities in schools.

This model can be accomplished if the following conditions are met: 1 ) the steps in the model are implemented correctly; 2) primary school teachers, senior teachers and supervisors have a high commitment to improve the professional competence of elementary school teachers and 3) senior teacher teaching schedules do not coincide with supervised teachers.

\section{Conclusion}

This supervision model has 3 main components: 1) needs analysis, 2) programming, and 3) program implementation. This has both practical and theoretical implications. This model is the development of existing models with the renewal of adding components: 1) initial meetings held on the tutor's initiative; 2) professional competency tests; And 3) input from tutors or senior teachers and learners.

The practical implications of the teacher-based professional competence-based supervisory model on thematic learning in the Curriculum 2013 can be used as a reference policy in the context of teacher development and can also be used as a reference to other theoretical constructions.

The theoretical implications strengthen the component in clinical supervision. Professional competence tests strengthen the findings of Nuchiyah (2004); Sapkova (2013); Baumert, et al. (2010); Zwiep and Benken (2013); Ball and Phelps (2008); as well as Hill and Ball's research (2005) who said that the academic ability of teachers will affect the performance of teachers, in the sense of good supervision results about the professional competence of teachers will provide a good teacher performance in learning that impact on improving student achievement.

On the other hand, theoretical implications undermine the results of research done by Balci, et al. (2011), Collins (2004), Holland and Garman (2001) this supervision model anticipates the constraints found in the research done by Balci, et al. (2011), Collins (2004), Holland and Garman (2001).

\section{Recommendation}

This model is the result of validation using Delphi Technique. This model requires a limited trial and a wider trial. This model refers to the Supervision Model based on High Teacher Professional Competency Based on the results of the assessment questionnaires in the limited trial schools and the 
broader test schools for the High School Competency Based Teacher Supervision Model conducted in Pekalongan City obtained an average score for 11 aspects assessed for 91.67. This means that it can be concluded that this model of supervision is effective (Hartono, M 2014). Referring to that, it is necessary to conduct further research to conduct limited trials and broader trials to discover the effectiveness of the Competency-Based Supervisor Model of Primary Teacher Teachers on Thematic Learning in the Curriculum 2013.

\section{Acknowledgement}

Thanks to fellow lecturers in the department of PGSD University of Jakarta who support this research and Mr / Ms Headmaster of elementary schools in Region III , Palmerah West Jakarta.

\section{References}

Afolakemi, Oredein and David, O Oloyede. (2007). "Supervision and quality of Teaching Personnel effect on student' Academic Performance". Educational Research and Review, 2(3) Academic Journal

Arifah, Neny. 2006. Pengembangan Supervisi Klinis untuk Meningkatkan Keterampilan Dasar Mengajar Guru. Tesis. Surabaya: Program Studi Manajemen Pendidikan Universitas Surabaya.

Balci, Ali, Demirkasimoglu, N., Erdogan, C. dan Akin, U. (2011). Turkish Teachers' and Supervisors' Metaphorical Perceptions about Supervisors. International Research Journal, Educational Research, 2 (10) : $1602-1610$.

Ball, D. L., Thames, M. H., \& Phelps, G. (2008). Content knowledge for teaching: What makes it special? Journal of Teacher Education, 59(5) : 389-407.

Baumert, J., Kunter, M., Blum, W., Brunner, M., Voss, T., Jordan, A., et al. (2010). Teachers' mathematical knowledge, cognitive activation in the classroom, and student progress. American Educational Research Journal, $47: 133-180$.

Boyle, B., While, D. and Boyle, T. (2004). A Longitudinal Study of Teacher Change: What Makes Professional Development Effective? The Curriculum Journal,. 15 (1) : 45 -68.

Collins, B.A. (2004). Teacher Performance Evaluation : A Stressful Experience from a Private Secondary School. Educational Research, 46 (1)

Delaney, S., Ball, D., Hill, H., Schilling, S., \& Zopf, D. (2008). Mathematical Knowledge for Teaching: Adapting U.S. Measures for Use in Ireland. Journal Mathematics Education, 11 : 171 -197.

Dodeen Hamzeh, et.al. (2012). The Effect of Teachers' Qualifications, Practises, and Perceprtions on Student Achievement in TIMMS Mathematics: A Comparison of Two Countries. International Journal of Testing, $12: 61-77$.

Driel, J.H., Beijaard, Douwe, and Verloop, Nico. (2001). Professional Development and Reform in Science Education. The Role of Teachers' Practical Knowledge. Journal of Reserch in Science Teaching., 38 (2) : $137-158$

Faisal. (2003). Kinerja Pengawas Pendidikan Agama Islam dalam Pengembangan Kompetensi Profesional Guru Agama Islam Sekolah Lanjutan Tingkat Pertama di Kota Bandung (Studi Terhadap Kinerja Pengawas Pendidikan Agama Islam Departemen Agama Kota Bandung. http://digilib.upi.edu/pasca/available/etd-0927106-132940/ (diunduh 20 Juni 2009).

Fullan, M., Cuttress, C. \& Kilcher, A. (2005). Eight forces for leaders of change. Journal of Staff Development, 26 (4) : 54-64

Handoko, T. Hani. (1995). Manajemen (edisi kedua). Yogyakarta : BPFE (Anggota IKAPI) Gajahmada Press

Hill, H., Rowan, B., \& Ball, D. (2005). Effects of Teachers' Mathematical Knowledge for Teaching on Student Achievement. Americans Educational Journal. Summer 2005, 42 (2) : 371 - $406 \mathrm{f}$

Holland, P \& Adams, P. (2002). Through the Horns of Dilemma between Instructional Supervision and the Summative Evaluation of Teaching. International Journal of Leadership in Education. 5 (3) : 227 -247.

Holland, P.\& Garman, N. (2001). Toward a Resolution of The Crisis of legitimacy in the Field of The Supervision. Journal of Curriculum and Supervision, 16 (2) : 95 - 111.

Kurniawan, Agung. (2005). Transformasi Pelayanan Publik.Yogyakarta: Pembaharuan

Mahmudi. 2005. Manajemen Kinerja Sektor Publik (Edisi I). Yogyakarta : Penerbit Buku UPP AMP YKPN

Nuchiyah. (2004). Kontribusi Kepemimpinan Kepala Sekolah dan Kinerja Mengajar Guru terhadap Prestasi Belajar Siswa Studi Deskripsi Analisis pada Sekolah Dasar Negeri se Kecamatan Buaran Kabupaten Serang tahun 2004. http://digilib.upi.edu/pasca/available/etd-1004106-115914/ (diunduh 29 Mei 2017].

Pidarta, Made. (2009). Supervisi Pendidikan Kontekstual Jakarta : Rineka Cipta. 
Rudiyanto. (2004). Pengaruh Pelaksanaan Supervisi Pendidikan Kepala Sekolah Terhadap Kemampuan Profesional Mengajar Guru Pendidikan Agama Islam di MTsN Ketanggungan Kabupaten Brebes. http://library.walisongo.ac.id/digilib/gdl.php?mod=browse\&op=read\&id=jtptiain-gdl-s1-2004rudiyanto3-703 (diunduh 17 Juni 2017)

Sahertian, Piet A. (2000). Konsep Dasar \& Teknik Supervisi Pendidikan dalam Rangka Pengembangan Sumber Daya Manusia. Jakarta : PT Rineka Cipta.

Sahertian, Piet A. (2000). Konsep Dasar \& Teknik Supervisi Pendidikan dalam Rangka Pengembangan Sumber Daya Manusia. Jakarta : PT Rineka Cipta.

Sapkova., Alesja. (2013). Study on latvian Matehmatics Teachers's espoused Beleifs about Teaching and Learning and Reported Practices. International Journal of Science and Mathematics Education 11 : 733-759.

Usman, Uzer. (2009). Menjadi Guru profesional. Bandung: PT Remaja Rosdakarya

Zwiep, S.G and Benken, B.M. (2013). Exploring Teachers' Knowledge and Perceptions across Mathematics and Science Through Contentrich learning Experiences in a Professional Development Setting. International Journal of Science and Mathematics Education (11) : 299-3 